\title{
Traditional Food Processing Technology as Industrial Resources in Indonesia
}

\author{
Kapti Rahayu Kuswanto* \\ * Faculty of Agricultural Technology, Gadjah Mada University \\ Yogyakarta, Indonesia
}

In the past decades, has Indonesia improved and intensified its food production program. Traditional techniques achieved practical results which with the passing of time grew to become one of the most important sectors of the country's local food industry. The technology of traditional food processing is simple, with an extremely low cost of production. There is a wide variety of special traditional foods of Indonesian origin, both fermented as well as nonfermented. Food fermentation has been improved and standardized as a result of the application of the basic principles of microbiology and biochemistry to industrial fermentation processes. This paper presents a review of the traditional Indonesian processed foods and their processing technologies, with particular emphasis on agricultural products. We discuss the development and improvement of food processing technologies applying the basic techniques of fermentation dehydration, and simple canning. Traditional fermented food products and their processing requirements are also discussed in this review. Legumes, cereals, and oilseeds have received considerable attention for the past several years, not only because of their abundance but also because of the variety of the products that can be derived from them. Coconut products include non-carbonated and carbonated coconut water, coconut snack items and coconut sugar,which are very common foods.

Indonesia has a rich variety of agricultural products as well as abundant animal and marine sources. As the population continues to grow at the rate of $2.34 \%$, Indonesia is going to have to review its present usage of all materials potentially suitable for foods.

Traditional foods are an important component in the Indonesian diet especially regarding their contribution as a source of proteins, calories and vitamins. Moreover, since most of them are made from a plant origin, they become more suitable as important diests for Indonesian people who seem to depend increasingly on plants rather than animal products. An enormous variety of traditional foods, both fermented as well as nonfermented, are easily, found in the market place and in the street food vendors.

Traditional techniques have achieved practical results which with the passing of time have grown to become one of the most important sectors of the country's local food industry. The technology of traditional food processing is simple with an extremely low cost of production. Like many other traditional foods, the process is carried out by traditional methods without sufficient hygiene precautions, and therefore natural contamination is always possible. We will present a review in this paper of traditional Indonesian processed foods and their processing technologies, with particular cmphasis on agricultural products. 
Table 1 Traditional Fermented Foods in Indonesia

\begin{tabular}{|c|c|c|}
\hline Row materials & Name of products & Productions (ton) \\
\hline \multicolumn{3}{|l|}{ Grains : } \\
\hline \multirow[t]{3}{*}{ Soy beans } & tempe & $1,315,100$ \\
\hline & kecap (soy sauce) & $1,270,400$ \\
\hline & tauco & 585,300 \\
\hline \multirow[t]{3}{*}{ Rice, glutinous } & tape ketan & 482,000 \\
\hline & brem liquid & 134,200 \\
\hline & brem solid & 86,500 \\
\hline \multicolumn{3}{|l|}{ Tuber } \\
\hline \multirow[t]{3}{*}{ Cassava } & tape ketela (peuyem) & 564,200 \\
\hline & growol & ND \\
\hline & gatot & ND \\
\hline \multicolumn{3}{|l|}{ Fruits/vegetables } \\
\hline Cucumber & pickle & ND \\
\hline Chinese cabbage & asinan & ND \\
\hline \multicolumn{3}{|l|}{ By products } \\
\hline \multirow[t]{2}{*}{ Peanut press cake } & oncom & 58,300 \\
\hline & dage & ND \\
\hline Coconut press cake & tempe bongkrek & ND \\
\hline Tofu press cake & tempe gembus & ND \\
\hline Sesame press cake & cabuk & ND \\
\hline \multirow[t]{3}{*}{ Fish } & terasi (fish paste) & ND \\
\hline & petis (fish sauce) & ND \\
\hline & peda (salted ferm. fish) & N D \\
\hline Milk & dadih (yogurt like) & ND \\
\hline
\end{tabular}

Source : Indonesian Statistics, 1995. ND : not detected.

\section{STATUS OF INDONESIAN FOOD INDUSTRY}

The food industry in Indonesia is rapidly expanding with emphasis on product diversification. However, it still remains small compared to other industries. About $82 \%$ of these industries are classified as small industries, as they have capital investments of less than $\mathrm{Rp} 100,000,000$, - . The sector of the food industry, involved with the processing of traditional food occupies only a minor portion of the industry. Most of the industries are not even included in the Directory of Manufacturing Establishments and do not fit into the categories listed.

The majority of the raditional food industries in Indonesia are considered to be small - scale industries or even back-yard operations. In fact, most of them are family-owned business using traditional methods of production.

In recent years, many scientists have shown increasing interest in traditional processed foods.
The Food and Nutrition Development and Research Center (Fandarc) and the Department of Food Research in some universities in particular has made research in the field of traditional foods as one of its priorities. Research has been done on both fermented and non - fermented foods. Emphasis is given not only to achieving a better understanding of the changes that occur in the processing of the foods, but also improving the methods of production, introducing mechanization, improving the quality, shelf - life, safety and packaging. Common traditional fermented foods as well as non-fermented foods are listed in Table 1 and 2 , respectively.

\section{TRADITIONAL FOODS FROM SOYA BEAN}

Soya beans are used as a raw material for a variety of traditional products, both fermented and non-fermented foods. Howerer, Indonesia does not produce many soya beans (approximately $1,250,000$ M. ton a year) Thus, it still depends 
mainly on imports to meet the demands of the industry.

Among the traditional fermented foods, made from soya beans, kecap, Tauco and tempe has been industrialized. However, these still are many home industries. The processing technology has been improved mainly for the preparation of inoculum, dehulling of the bean, and the steaming and packaging system. The research was conducted to select the most suitable strains of fungus for their production. In the case of tempe, the fungus selected was the strain of Rhizopus oligosporus, which is able of producing a specific flavor. And for kecap the fungus selected was Aspergillus oryzae or A. sojae The technology of preparing inoculum has been improved and industrialized. Traditionally the mold fermentation stage of the kecap production depends on the chance inoculation of various species of remaining fungus from trays used for the molding process and from the environment. Use of a pure culture ensures that the fermentation will be carried out by the desired fungus and a consistently good quality product is obtained. The fermentation processes has been improved by controlling the temperature, aeration system and humidity.

After fungus fermentation, the koji is usually put into earthenware jars, mixed with brine. This brine fermentation stage requires a large area and each individual jar has to be opened and closed daily. Some of the kecap industry use large stainless steel containers, which are fitted with mechanically controlled covers, and pumps are used to siphon out the liquid. Pasteurization of the final product, in the production of semiautomatic bottling and use of disposable polyester bottles have also contributed to improving the process. Use of polyester bottles in particular is a definite improvement over the use of recycled bottles not only in terms of hygiene but also in terms of preservation.

In the production of tempe, one of the important steps is dehulling the beans after cooking. A good tempe will be occurred if the hull is removed.

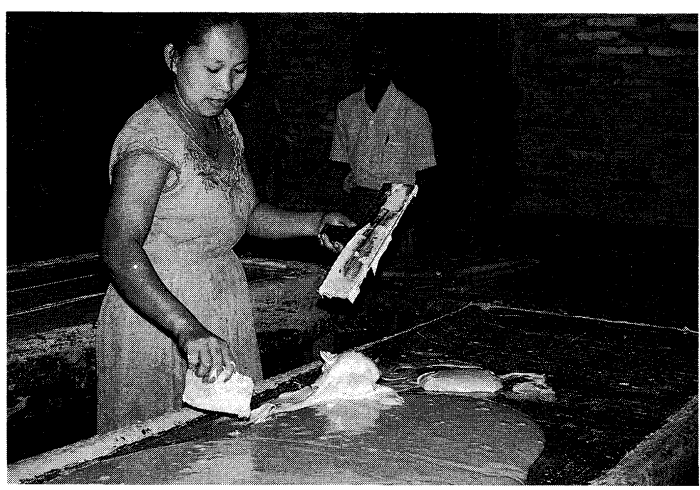

Photo. 1 Brem cake production After concentration of saccharified rice, knead for decoloring.

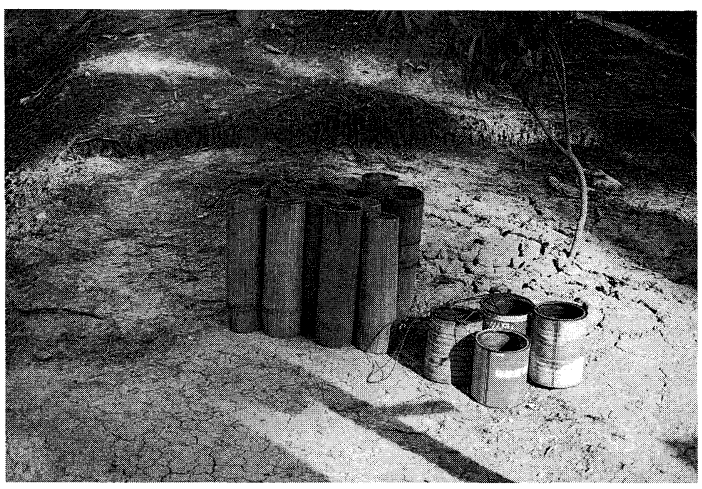

Photo. 2 Sap of coconut palm

The sap correct into bamboo tube.

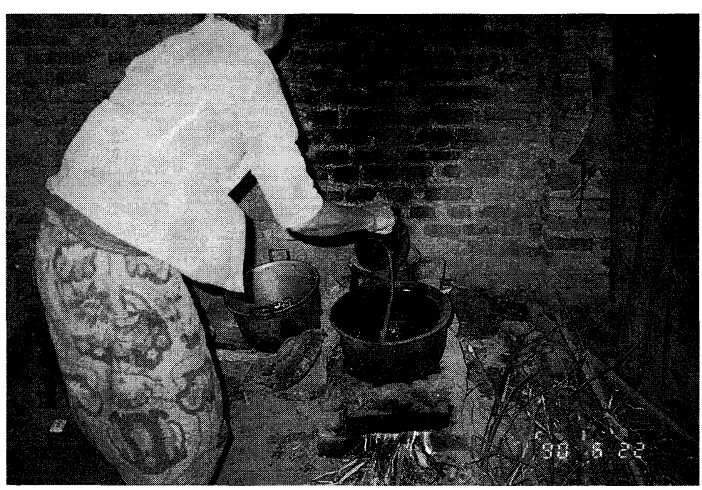

Photo. 3 Conceutration of coconut sap Carried out in a iron pot. 
Table 2 Traditional non-fermented foods in Indonesia

\begin{tabular}{|l|l|r|}
\hline \multicolumn{1}{|c|}{ Raw materials } & \multicolumn{1}{|c|}{ Name of products } & Production (ton) \\
\hline Grains & tahu (soy bean curd) & $2,177,100$ \\
Soy beans & rice chip & 455,200 \\
Rice & noddle & 534,500 \\
& sauce & N D \\
Peanut & sweet & N D \\
Coconut & brown sugar & 643,000 \\
Coconut sap & geplak & N D \\
Coconut meat & beverages & ND \\
Coconut water & sale (dried banana) & ND \\
Fruit & pindang (salted boiled fish) & N D \\
Banana & ikan asap (smoke fish) & ND \\
Fish &
\end{tabular}

Source : Indonesian Statistics, $1995 . \quad$ ND : not detected.

Some of the tempe industry use mechanical dehulling before soaking and cooking. Traditionally the starter culture is prepared by collecting small pieces of a previously fermented tempe. The collected pieces of tempe are air-dried or sun-dried, ground to a smooth powder and used as inoculum. In some cases, the surfaces of a previously fermented tempe cake where most of the mycellium is found may be sliced, sun-dried, ground and used as inoculum ( $\mathrm{Ko}$ and Hesseltime, 1979). The other type of traditional inoculum is usar, prepared by using leaves of either Erythrina Sp., Hibiscus dimilis $B$ or $H$. filiaceus. The lowersides of these leaves are covered with downy hairs (trichomos) to which the mold mycellium and spore can adhere.

For the fermentation step, after inoculation the beans are usually wrapped in banana leaves or other leaves. Furthermore, the people used perforated plastic bags and bloc fermentation techniques.

Tauco is one of the Indonesian fermented foods which are particularly found in west Java. Traditionally tauco is used as flavoring agent in Indonesian preparation consisting of meat, fish or vegetables.

Tauco is prepared through mold fermentations and then followed by brine fermentation. The first stage of the preparation of tauco is using soybeans

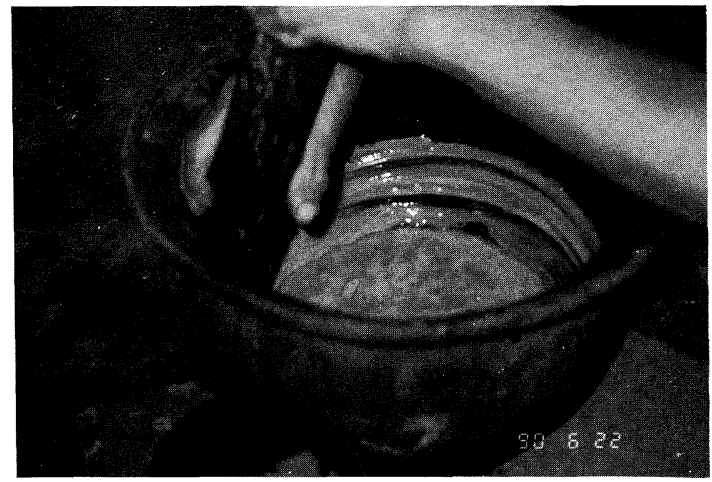

Photo. 4 Cristallization of palm sugar, mother crystal will get by

inoculated with Rhizopus oligosporus, R. Oryzae, and Aspergillus oryzae which may work individually or in combination. Microorganisms which are active during brine fermentation are lactic acid bacteria (Lactobacillus delbrueckli) and osmophilic yeast (Hansenulla sp. ). After brine fermentation is complete, the brine is drained, and palm suger is added. The last step is to cook it and directly fill into bottles. Tauco is available in a semisolid form obtained by sun drying of the liquid product to a final moisture content of $25 \%$.

Generally kecap (soy sauce) is made from black soybeans and tauco from yellow soybeans. Tauco consists of the whole soybean, while kecap 
consists of extracted soybeans. The technology of tauco production still remains traditional.

In the traditional non-fermented soya bean products are various type of soya bean curd (tahu). The different types of this product are caused by different coagulating agents used, the moisture content and color. For the production of tahu, the raw soybean milk is boiled and then coagulated with coagulating agents such as "batu tahu" or calcium sulfate. The curd form of tahu, is made after the curd is scooped into individual moulds lined with cloth and then placed on wooden trays which are stacked and pressed to squeeze water out of the curd. The pressed curd or tahu is then placed in the water to cool. There are various kinds of tahu is depending on the texture, moisture content, and the porous size. The developing of the processing technology developed was a dehulling and grinding system, and selection of suitable coagulating agents.

\section{TRADITIONAL FOODS FROM RICE}

The production of rice is estimated to be about $40 \%$ of the total production of food crops in Indonesia. Several foods, both fermented or nonfermented, are prepared from rice or glutinous rice. One of the famous non-fermented traditional foods from rice is rice chip, which is known locally as "kerupuk gendar" "kerak" or "lempeng". This product is very tasty and popular in Central Java, particularly with low income families.

Rice chip production is conducted by small family industries or home industriest. The active ingredient involved in the rice chip product is called "air bleng" or "cetiled", which has a salty taste, and is collected from a mineral well. Traditionally the production of rice chip is as follows. After cleaning and washing, rice is steamed until half-cooked, and mixed with "air bleng" as solution or solid. This solution together with rice is then cooked, and steamed again until completely cooked. Them it is pounded into a sticky smooth product, mold-sliced and sundried. The product is sold and served after being deep fried in oil.

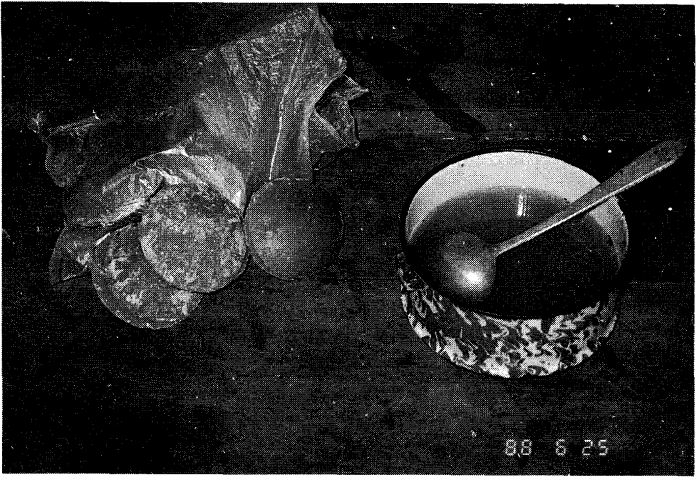

Photo. 5 Concentrated sugar solution and product of coconut sugar.

The active ingredient in "bleng" is reported to be borax or boric acid, which is present in dried "bleng" as much as $4 \sim 7 \%$. Boric acid $\left(\mathrm{H}_{3} \mathrm{BO}_{3}\right)$, orthoborics acid occurs in nature as mineral sasolite, white granules or powder. Borax is also known as pyroborate, diborate or sodium borate. In addition to rice chip production, it is also used for noodles and macaroni. Noodle and macaroni producers usually use pure boric acid, which is a white crystal produced from pharmaceutical industries. The mechanical action of rice chip production is still not well understood.

A famous fermented food product from glutinous rice in Indonesia is brem cake and brem liquid as well. For the production of brem, first tape ketan is prepared.Tape ketan is prepared form glutinous rice (Oryza sativa glutinosa) which may be the black or the white variety. The incubation processing is done in a glass jar or earthen jar.

Brem cake is made by prolonged tape fermentation up to $5 \sim 6$ days and then pressed, to release the juice. The juice is then concentrated by gradual heating and spread into layers of about $1.0 \mathrm{~cm}$ thick followed by drying in the sun or air dried. This product is a very popular fermented food in the East and Central Java, characterized by a sweet alcoholic and slightly sour taste, yellowish white in color and is easily dissolved in the mouth. The processing technology has been improved by selecting the suitable inoculum, and using a hydraulic press and electric mixer. 


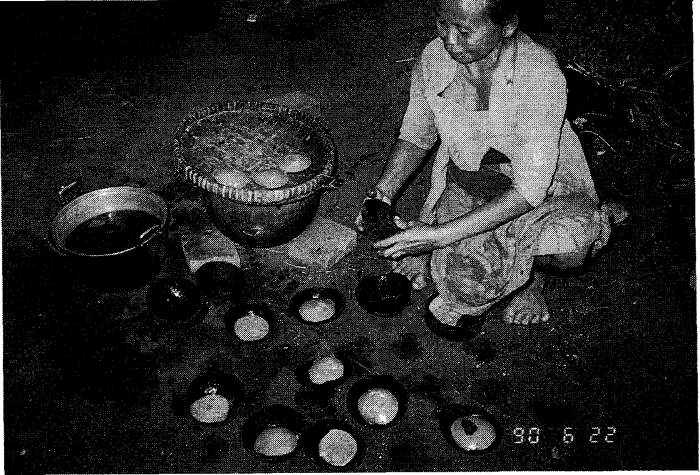

Photo. 6 Crystallization of concentrated palm sap and palm sugar product.

The production of brem liquid is slightly different with brem cake, especially for the inoculum or fermentation condition. This product has more alcoholic content. After pressing the juice, the liquor is transferred into a screw capped for further alcoholic fermentation at $25^{\circ} \mathrm{C}$ for 14 days. The brem wine is aged for 2 months or more at room temperature or cooler.

The processing technology of brem wine making is still traditional, especially during fermentation. The selection of suitable microorganisms for making brem wines has been done by JENNY et al., 1984.

\section{TRADITIONAL FOODS FROM COCONUT AND FRUIT}

The most popular traditional foods are coconut sugar or palm sugar, which are characterized by better taste compared to cane or bit sugar. Coconut sugar or the local name "gula kelapa" is similar to other palm sugar such as "gula aren" and "gula lontar" which is made from coconut sap ( "nira"). The juice or sap are taken from the peduncle of the male flower. After preliminary treatment, the flower spikes are cut off and the sugary juice is collected in a vessel made from bamboo or a plastic pot.

The boiling of the juice is done in open pans, in order to make it concentrated. To prevent the liquid from boiling over, various hard objects are put into it, such as coconut endosperm or cuts of wood. As soon as the sugar is set, it is stirred and poured into molds like coconut shells. The amount of sugar in fresh juice varies from 5 to 15 percent. The albuminous matter is commonly associated along with the sucrose in the juice, which makes the sugar soft, hygroscopic, and ready to ferment.

One of the products from fruit is dried banana or "sale pisang". The moisture content of this product is about $15 \sim 25$ percent. It has a brown color, a sweet taste and specific flavor. The drying period usually takes 3 to 5 days.

The origin of sale pisang is not known, though it is believed that sale pisang originated from West Java. The traditional method of sale pisang making is very simple including skin peeling and sun-drying. During drying, the banana is pressed carefully each successive day, so that the final product will have a flat shape. Sun-drying is done on a bamboo mat which has been covered by rice straw.

The principal chemical reactions known during preparation are browing reactions and conversion of the remaining starch of the banana into sugars. The browning reactions, both enzymatic and non - enzymatic, result in a brown color, and the conversion of starch to sugar produces a sweeter taste than the original banana. There are special varieties of banana for making this product. This is mainly eaten as snack food and has been popular in Indonesia.

To improve the traditional method of sale preparation, many research projects have been carried out.

\section{REFERENCES}

1) ANONYmous : Statistical Year book of Indonesia Biro Pusat Statistik Jakarta Indonesia (1990)

2) ANonymous : Vademekum Pemasaran. Sub Direktorat Pengembangan Pemasaran. Direktorat Bina Sarana. Departemen Pertanian, Jakarta (1981)

3) Diten, K. S., and Hesseltine, C. W. : Economis Microbiology, 4, 115 (1979)

4) Saono, J. K. D., Tomomattsu, A., Matsuyama, A., Kozaki, M. and Baba, T: The preparation of brem ragi ; An improved 
method. International Symposium on Agricultural product processing technology. July31 August 2, 1984. Bogor, Indonesia.

5) Saono, S., Winarno, F. G. and Karyadi, D. (eds.) : Traditional Food Fermentation as Industrial Resources in ASCA Countries. Proceeding of a Technical Seminar. February 9 11, 1981, Medan, Indonesia (1982)

6) Sayekti, B. and Muryati : Penelitian Mutu pisang sale. Balai Penelitian dan Pengembangan Industry, Departement Perindustrian, Semarang (1981)

7) Steinkraus, K. H. (undated) : Contribution of Asian Fermented Foods to International Food Science and Technology. Cornell University Ithaca,N. Y. 14458.

8) Winarno, F. G. : Traditional Technologies of Indonesia. Worshop on Traditional Foods Conservation and Processing Technologies, CFTRI, Mysore, July18 26 (1983)

\section{インドネシアのエ業資源である 伝統食品製造工業}

$$
\text { カプティ ラハヤ クスワント* }
$$

*ガジャマダ大学農業工学部 (Yogyakarta, Indonesia)

インドネシアは，単純な工程で低価格の小企業に適応 する固有の伝統食品を数多くもっている。特にこの 10 年間は製品の多様化などで, 小企業, 家族レベルの加工 業であっても, 食品微生物や食品衛生の理解も高まって きた。特に栄養食品開発研究センタ一や大学の研究室が 伝統食品を研究し，これらを資源と考えて工業化への開 発を目論むようになった。

この論文はこれらを基盤としてインドネシアの農産物 の伝統加工食品および加工技術の改良開発について特に 大豆，米，ココ楖子を主として短かく解説してある。

大豆の場合，テンペとケチャップ (醬油類似)をあげ， 前者はRhizopus obigosporusを後者にはAspergillus oryzaeなどを選択株として使用, 接種法なども改良され た。剝皮，蒸煮などの操作も機械化された。

米の伝統食品は米チップのケルプック, 中部ジャワの ケラクやブレムケーキを採りあげ，製法とその背景につ いて述べた。

またココ楖子の食品として, サトウキビやビートの糖 よりすぐれた梛子糖の製法を簡略に記載している。 